Journal of Southeast Asian

2011

\title{
Appendix K: Survey Instrument
}

\author{
Wayne E. Wright \\ University of Texas, San Antonio, wewright@purdue.edu \\ Sovicheth Boun \\ The State University of New York at Fredonia, bounsovicheth@gmail.com
}

Follow this and additional works at: https://docs.lib.purdue.edu/jsaaea

\section{Recommended Citation}

Wright, Wayne E. and Boun, Sovicheth (2011) "Appendix K: Survey Instrument," Journal of Southeast Asian American Education and Advancement. Vol. 6 : Iss. 1, Article 12.

DOI: $10.7771 / 2153-8999.1028$

Available at: https://docs.lib.purdue.edu/jsaaea/vol6/iss1/12

This document has been made available through Purdue e-Pubs, a service of the Purdue University Libraries. Please contact epubs@purdue.edu for additional information.

This is an Open Access journal. This means that it uses a funding model that does not charge readers or their institutions for access. Readers may freely read, download, copy, distribute, print, search, or link to the full texts of articles. This journal is covered under the CC BY-NC-ND license. 


\section{NAFEA Southeast Asian American Community Survey}

\section{Overview and Demographics}

Welcome to the Southeast Asian American Survey, sponsored by the National Association for the Education and Advancement of Cambodian, Laotian, and Vietnamese Americans (NAFEA).

This survey will allow you to share your thoughts and experiences related to K-12 education, higher education, Southeast Asian languages, and Southeast Asian communities.

The survey is intended for current Southeast Asian American college and university students, or recent graduates. Southeast Asian American high school students are also welcomed, but should skip the section on higher education.

This survey should take about 20 to 30 minutes to complete. Your answers will help NAFEA understand the successes and challenges faced by Southeast Asian Americans and communities, and to advocate for needed policies and programs.

Your answers are completely confidential. You will not be asked for your name or e-mail address. You may skip any question you do not wish to answer. Results will be published in the Journal of Southeast Asian American Education and Advancement (www.jsaaea.org). Questions or comments about this survey may be directed to NAFEA President Dr. Chhany Sak-Humphry at sak@hawaii.edu, or Executive Board Member Dr. Wayne E. Wright at drwaynewright@gmail.com.
1. Age
( 16 or under
C $17-20$
(C) $21-24$
C $25-29$
( $30-49$
(C) $50+$

\section{Gender}

ए Male

- Female 


\section{NAFEA Southeast Asian American Community Survey}

\section{Place of birth:}

C Cambodia

() Laos

(6) Thailand

() United States

() Vietnam

Other (please specify)

\section{Race/Ethnicity (check all that apply)}

— African American

C Chinese

$\Gamma$ Hispanic

$\Gamma$ Hmong

ГKhmer (Cambodian)

$\lceil\mathrm{Khmu}$

$\Gamma$ Laotian

Г Lue

$\lceil$ Mien

$\lceil$ Native American

ГThai

Г Thaidam

$\Gamma$ Vietnamese

$\Gamma$ White

Other (please specify)

5. In which state do you currently live?

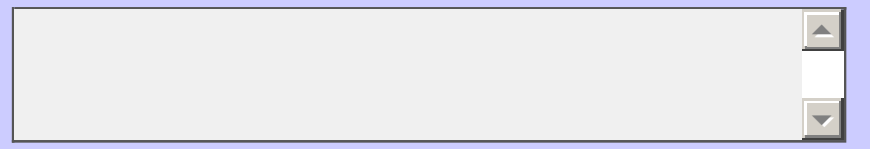

\section{Education}




\section{NAFEA Southeast Asian American Community Survey}

6. In what grade level did you first begin school in the United States?
() Preschool/Pre-Kindergarten
(6) 4th grade
(6) 9th grade
C Kindergarten
(C) 5th grade
(C) 10th grade
(1st grade
6. 6th grade
11th grade
(1) 2nd grade
(6) 7th grade
12th grade
C. 3rd grade
8th grade
College/University

7. Were you classified as an English Language Learner (ELL) or Limited English Proficient (LEP) student when you first began school?
( Yes
() No
Don't know

If yes, about how many years were you classified as an ELL or LEP student?

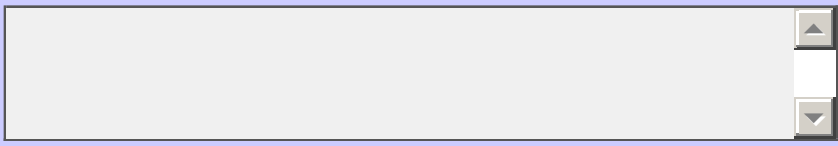

8. In which state(s) did you attend K-12 schools?

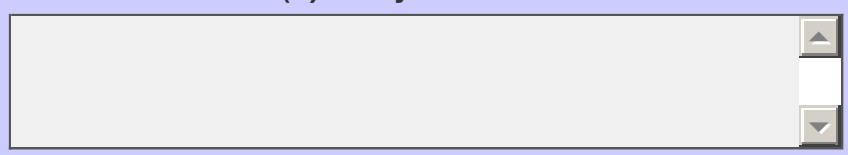

9. Current year in school
(1) High School
(6) Technical/Trade School
College - Freshman
C College - Sophomore
C College - Junior
C College - Senior
() Graduate Student
Recent Graduate (indicate year in box below)
Attended some college but not currently attending (indicate highest level completed in box below)
Other or Comments (if any) 


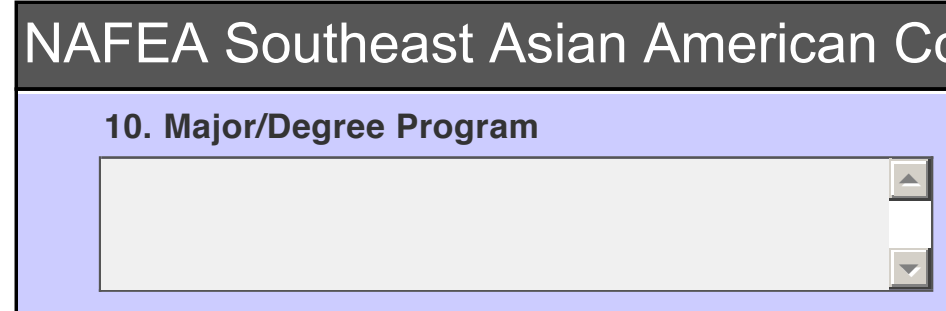

\section{K-12 Education Experience}

11. Approximately how many other Southeast Asian American students were in your schools?

\begin{tabular}{|c|c|c|c|c|c|c|c|}
\hline & $\begin{array}{c}\text { Less than } \\
1 \%\end{array}$ & $1-9 \%$ & $10-24 \%$ & $25-49 \%$ & $50-74 \%$ & $75 \%$ or more & $\begin{array}{c}\text { Not } \\
\text { applicable }\end{array}$ \\
\hline Elementary School & O & C & C & O & O & O & O \\
\hline $\begin{array}{l}\text { Middle School/Junior } \\
\text { High School }\end{array}$ & 0 & 0 & 0 & 0 & 0 & 0 & 0 \\
\hline High School & O & 0 & C & O & O & O & O \\
\hline
\end{tabular}

Comments (if any)

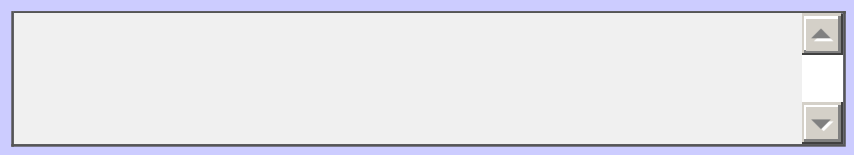

12. In the K-12 schools you attended in the U.S., about how many Southeast Asian Americans worked in the following positions:

$\begin{array}{lcccccc} & 0 & 1-2 & 3-5 & 6-9 & 10 \text { or more } & \text { Not applicable } \\ \text { Administrators: } & 0 & 0 & 0 & 0 & 0 & 0 \\ \text { Teachers: } & 0 & 0 & 0 & 0 & 0 & 0 \\ \text { Paraprofessionals: } & 0 & 0 & 0 & 0 & 0 & 0 \\ \text { Staff (e.g., office, } & 0 & 0 & 0 & 0 & 0 & 0\end{array}$

custodial, cafeteria,

etc.)

Comments (if any)

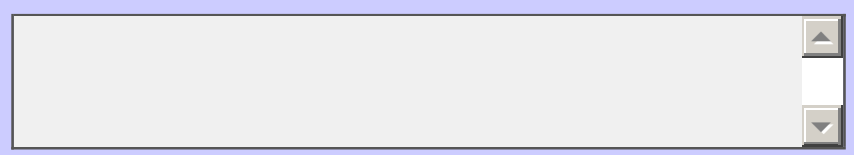




\section{NAFEA Southeast Asian American Community Survey}

13. How many of your own teachers were Southeast Asian Americans?

0

() $1-2$

(.) $3-5$

() $6-9$

(1) 10 or more

O Not applicable

Comments (if any)

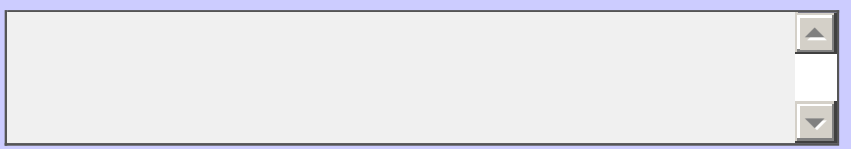

14. How often did you face difficulties understanding instruction, participating in class, or completing assignments due to your level of English language proficiency at these grade levels?

Never Rarely Occasionally Frequently Not applicable

\begin{tabular}{lll} 
K - 2nd & 0 & 0 \\
3rd - 5th & 0 & 0 \\
6th - 8th & 0 & 0 \\
9th - 12th & 0 & 0 \\
Comments (if any) & & \\
\hline & &
\end{tabular}

\section{Bilingual Education Participation}

In Bilingual Education Programs, students with limited English proficiency are taught to read and write in their native language first, and are also taught one or more other content areas in their native language. The amount of native language instruction is decreased as the amount of English instruction is increased as students progress in learning English.

Bilingual Education also includes dual language (or Two-Way Immersion) programs where students learn to read and write in English and their native language at the same time. These classroom may also have English-only students who are learning the native language of the other students.

* 15. Were you ever in a bilingual education program?
Y Yes
( No
Not sure 


\section{NAFEA Southeast Asian American Community Survey}

\section{Bilingual Education Program Experience}

In Bilingual Education Programs, students with limited English proficiency are taught to read and write in their native language first, and are also taught one or more other content areas in their native language. The amount of native language instruction is decreased as the amount of English instruction is increased as students progress in learning English.

Bilingual Education also includes dual language (or Two-Way Immersion) programs where students learn to read and write in English and their native language at the same time. These classroom may also have English-only students who are learning the native language of the other students.

16. How many years were you in the bilingual education program?
(.) 1-2 years
(.) 3-4 years
(1) $5-6$ years
C 7 or more

Comments (if any)

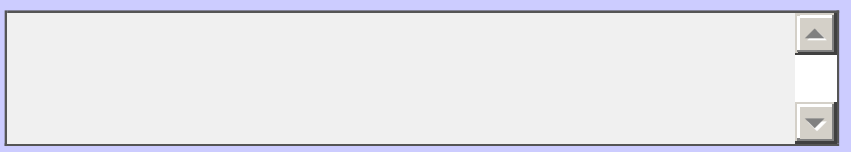

17. At which school levels were you in a bilingual program? (Mark all that apply)

Г Elementary School

Г Middle school/Junior High School

$\Gamma$ High School

Comments (if any)

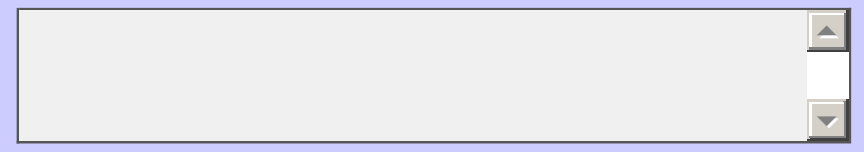

18. Who provided literacy and/or content instruction in your native language? (Mark all that apply)

$\Gamma$ A bilingual classroom teacher

Г A bilingual paraprofessional (e.g., teacher aid, instructional assistant, etc.)

- A bilingual specialist teacher (i.e., a teacher who traveled to different classrooms, or pulled students out of regular classrooms to provide bilingual instruction)

Comments (if any)

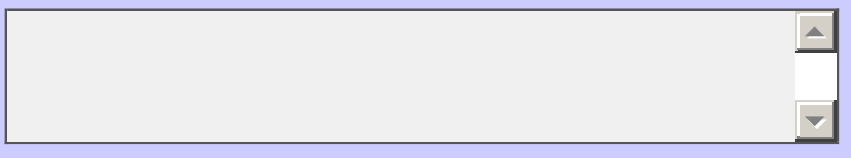




\section{NAFEA Southeast Asian American Community Survey}

19. How effective was the bilingual program?

( Very effective

Somewhat effective

(C) Not effective

Comments (if any)

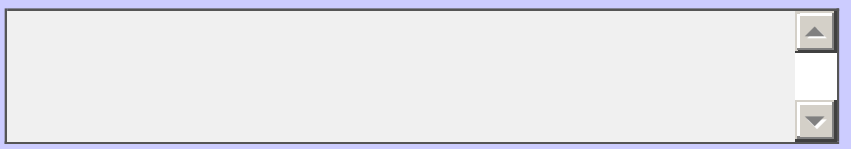

\section{ESL, ESOL, ELD, and Sheltered Instruction Program Participation}

Schools are required to help students with limited English proficiency by providing programs to help them learn English. Such programs are usually called English as a Second Language (ESL), English for Speakers of Other Languages (ESOL) or English Language Development (ELD).

Schools are also required to help such students learn the same academic content as English fluent students. These programs have different names, such as Specially Designed Academic Instruction in English (SDAIE), Sheltered English Immersion (SEI), Sheltered Instruction (SI). Below these will all be referred to as "Sheltered Instruction (SI)".

* 20. Were you ever in one of the following programs:

English as a Second Language (ESL)

English for Speakers of Other Languages (ESOL)

English Language Development (ELD)

Sheltered Instruction (SI)

(1) Yes

( No

(6) Not sure

Comments (if any)

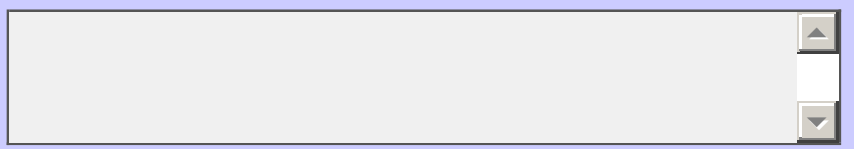

\section{ESL, ESOL, ELD, and Sheltered Instruction Program Experiences}

Schools are required to help students with limited English proficiency by providing programs to help them learn English. Such programs are usually called English as a Second Language (ESL), English for Speakers of Other Languages (ESOL) or English Language Development (ELD).

Schools are also required to help such students learn the same academic content as English fluent students. These programs have different names, such as Specially Designed Academic Instruction in English (SDAIE), Sheltered English Immersion (SEI), Sheltered Instruction (SI). Below these will all be 


\section{NAFEA Southeast Asian American Community Survey}

referred to as "Sheltered Instruction (SI)".

21. How many years were you in an ESL, ESOL, ELD, or Sheltered Instruction program?

(6) 1-2 years

(C) $3-4$ years

(6) 5 years

( 7 or more

C. Not sure

Comments (if any)

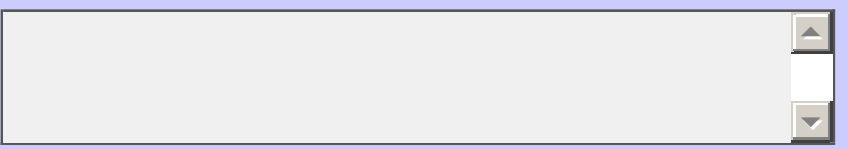

22. At which school levels did you receive ESL, ESOL, ELD, or Sheltered instruction?

$\square$ Elementary School

Г Middle School/Junior High School

$\square$ High School

Other (please specify)

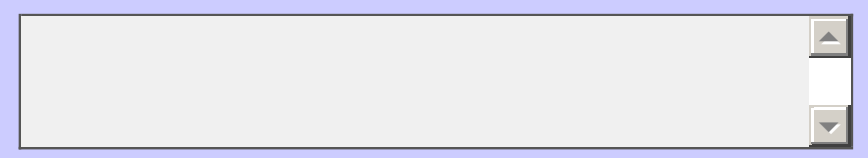

23. Who provided your ESL, ESOL, ELD or Sheltered Instruction? (check all that apply)

ГThe regular classroom teacher

- A specialist who pulled me out of the classroom

Г A paraprofessional (e.g., teacher's aide, bilingual aide, instructional assistant, etc.)

$\lceil$ Not sure

Other (please specify)

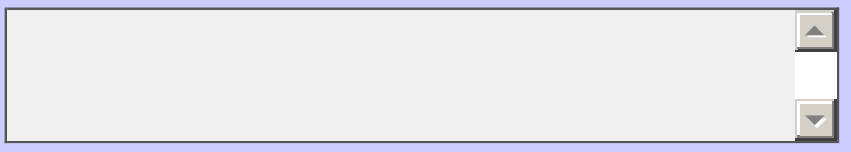




\section{NAFEA Southeast Asian American Community Survey}

24. How effective was your ESL, ESOL, ELD or Sheltered Instruction?

( Very effective

Somewhat effective

(C) Not effective

Comments (if any)

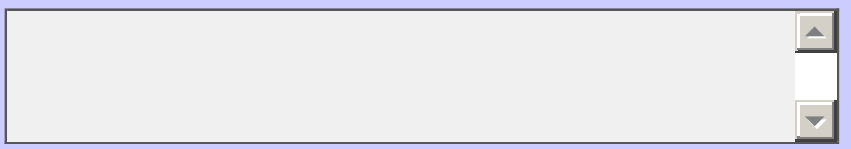

\section{Foreign (World) Language Classes for Native Speakers Participation}

9. Foreign (World) Language Classes for Native Speakers

Most secondary schools, and some elementary schools have foreign (or world) language classes. Some schools have language classes designed for native speakers. Such courses for Southeast Asian American students are usually called Hmong for Hmong Speakers, Lao for Lao Speakers, Khmer for Khmer Speakers, and Vietnamese for Vietnamese Speakers. These classes may also be called Heritage Language programs.

Some schools only offer these classes before or after school, including some for foreign language credits.

* 25. Have you ever received instruction in your native language at school through a foreign (world) language course or program?
Y Yes
(1) No
(1) Not sure

Comments (if any)

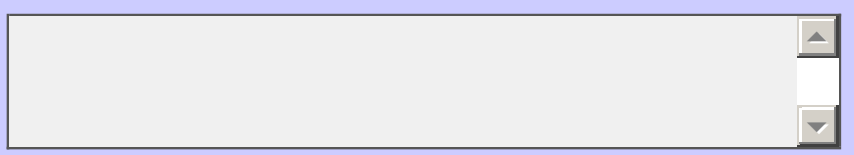

\section{Foreign (World) Language Classes for Native Speakers Experiences}

Most secondary schools, and some elementary schools have foreign (or world) language classes. Some schools have language classes designed for native speakers. Such courses for Southeast Asian American students are usually called Hmong for Hmong Speakers, Lao for Lao Speakers, Khmer for Khmer Speakers, and Vietnamese for Vietnamese Speakers. These classes may also be called Heritage Language programs.

Some schools only offer these classes before or after school, and students may or may not earn foreign language credit for taking them. 


\section{NAFEA Southeast Asian American Community Survey}

26. How many years did you participate in Foreign (World) Language Classes for native speakers?
( 1 year
(1) 2 - 3 years
(.) 4 - 6 years
7 years or more

Comments (if any)

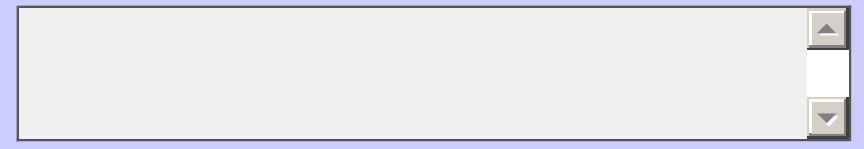

27. At which school levels did you take Foreign (World) Language Classes for native speakers? (Mark all that apply)

「Elementary School

Г Middle School/Junior High School

ए High School

Comments (if any)

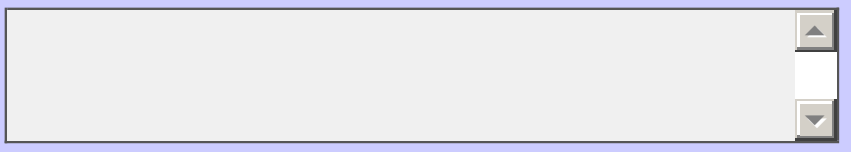

28. When were these Foreign (World) Language Courses for native speakers offered?

$\lceil$ During the regular school day

Г Before school

$\lceil$ After school

「On weekends

Comments (if any) 
Wright and Boun: Appendix K: Survey Instrument

\section{NAFEA Southeast Asian American Community Survey}

29. Who taught these Foreign (World) Language Classes for native speakers? (Mark all those that apply)

$\square$ A full-time foreign language teacher

Г A paraprofessional (e.g., teacher's aide, instructional assistant, etc.)

$\square$ A part-time employee or volunteer from the community

$\lceil$ Not sure

Comments (if any)

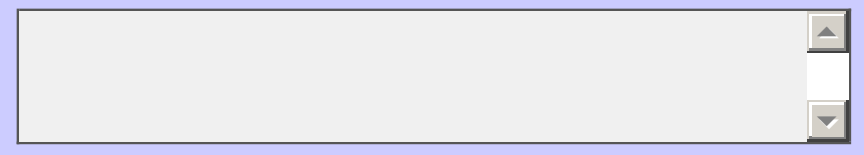

30. How effective were these Foreign (World) Language Classes for native speakers?

Very effective

(6) Somewhat effective

(O) Not effective

Other (please specify)

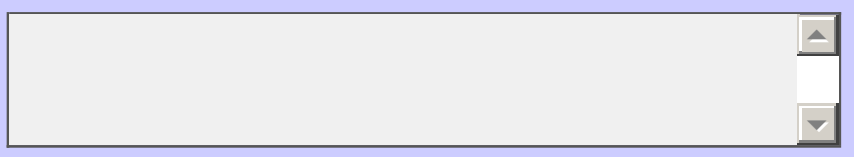

\section{Southeast Asian American Inclusion in the Curriculum}

31. How often did you have opportunities to learn about Southeast Asian history and cultures in your K-12 classrooms?

Frequently

Occasionally

(O) Rarely

() Never

(0) Unsure

Comments (if any)

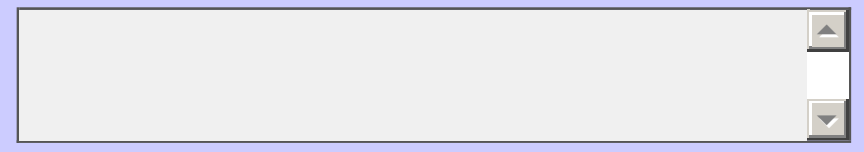




\section{NAFEA Southeast Asian American Community Survey}

32. How often did your textbooks or curricular materials include information related to Southeast Asia or Southeast Asian Americans?

Frequently

Occasionally

Rarely

() Never

() Not sure

Other (please specify)

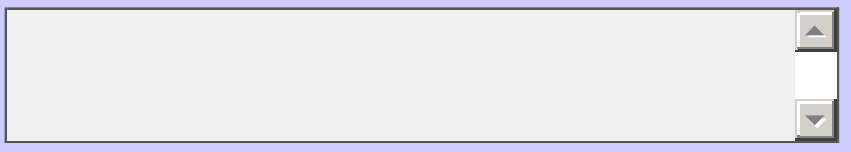

33. How much did your K-12 teachers know about Southeast Asian history, cultures, and community issues?

A lot of knowledge

C Some knowledge

() Little knowledge

No knowledge

Other (please specify)

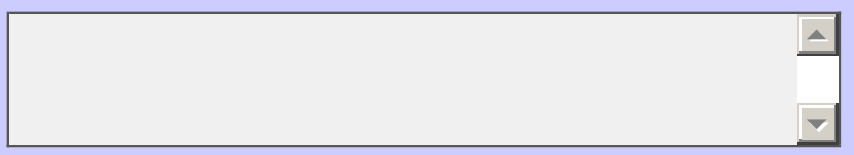

11. Quality of Teaching and Learning 


\section{NAFEA Southeast Asian American Community Survey}

34. Please indicate your level of agreement with the following statements:

\section{Strongly Agree Agree}

Most of my teachers

were highly qualified

to teach linguistically

and culturally diverse

students.

There was too much

focus on preparing for

state test in my

classrooms.

The pressure of state tests led to more

effective instruction in

my classrooms.

The pressure of state

tests led to less

interesting instruction

in my classrooms.

Some subjects not on

the state tests

received little to no

instruction in my

school.

My test scores

provided an accurate

measure of my

academic ability.

Important decisions

such as grade-level

promotion and high

school graduation

should be made

based only on a

student's test scores.

Comments (if any)
O

o

c

c

C

o

C
C

o

( )

c

o

O

c
Disagree

o

O

C

O

O

C

C
Strongly Disagree

Unsure

○

C

C

O

○

O

C

O

O

c

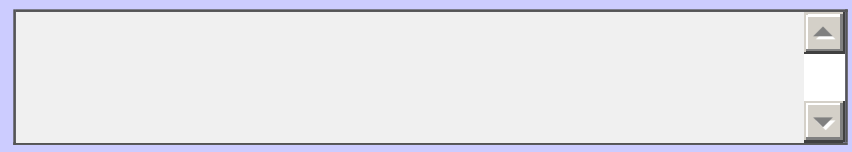

12. Consequences of State Tests 


\section{NAFEA Southeast Asian American Community Survey}

35. In your schools, how many Southeast Asian American students ...

\begin{tabular}{|c|c|c|c|c|c|}
\hline & $\begin{array}{c}\text { None that I know } \\
\text { of }\end{array}$ & A few & Less than half & More than half & Almost All \\
\hline $\begin{array}{l}\text { Had to repeat a grade } \\
\text { level because they } \\
\text { failed the state test? }\end{array}$ & O & O & 0 & 0 & O \\
\hline $\begin{array}{l}\text { Had to take } \\
\text { mandatory test } \\
\text { preparation classes } \\
\text { as an "elective"? }\end{array}$ & 0 & 0 & 0 & 0 & 0 \\
\hline $\begin{array}{l}\text { Had to take } \\
\text { mandatory test } \\
\text { preparation classes } \\
\text { before or after school, } \\
\text { or on weekends? }\end{array}$ & 0 & 0 & 0 & 0 & 0 \\
\hline $\begin{array}{l}\text { Dropped out of school } \\
\text { over concern about } \\
\text { passing a high-school } \\
\text { exit exam? }\end{array}$ & 0 & 0 & 0 & 0 & 0 \\
\hline $\begin{array}{l}\text { Completed } 12 \text { th grade } \\
\text { but were denied a } \\
\text { diploma for failing a } \\
\text { high-school exit } \\
\text { exam? }\end{array}$ & O & 0 & O & O & 0 \\
\hline
\end{tabular}

Comments (if any)

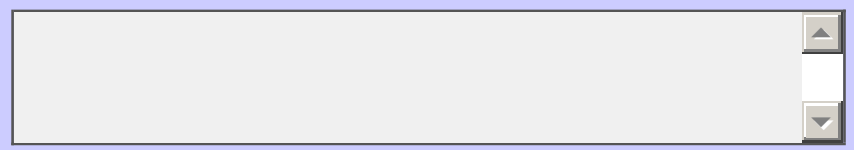

\section{Southeast Asian Language Proficiency and Use}

36. Which Southeast Asian language do you consider to be your native or heritage language?
Hmong
( Lao
(1) Khmer (Cambodian)
C Vietnamese

Others (please specify)

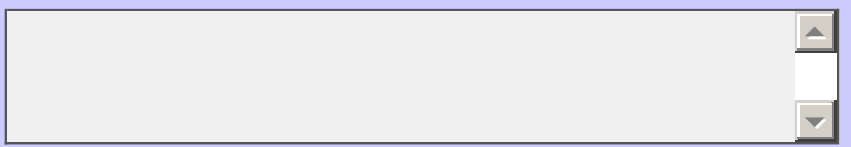


Wright and Boun: Appendix K: Survey Instrument

\section{NAFEA Southeast Asian American Community Survey}

37. How would your rate your level of proficiency in this language?

$\begin{array}{lccccc} & \text { Very good } & \text { Good } & \text { Fair } & \text { Poor } & \text { None } \\ \text { Listening } & 0 & 0 & 0 & 0 & 0 \\ \text { Speaking } & 0 & 0 & 0 & 0 & 0 \\ \text { Reading } & 0 & 0 & 0 & 0 & 0 \\ \text { Writing } & 0 & 0 & 0 & 0 & 0\end{array}$

Comments (if any)

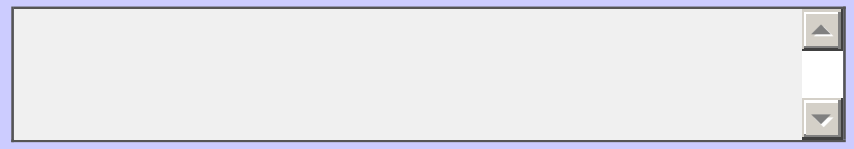

38. How often do you use this language when communicating with the following people?

$\begin{array}{lccccc} & \text { Frequently } & \text { Occasionally } & \text { Rarely } & \text { Never } & \text { N/A } \\ \text { Parents } & 0 & 0 & 0 & 0 & 0 \\ \text { Grandparents } & 0 & 0 & 0 & 0 & 0 \\ \text { Other older relatives } & 0 & 0 & 0 & 0 & 0 \\ \text { Siblings } & 0 & 0 & 0 & 0 & 0 \\ \text { Other relatives of the } & 0 & 0 & 0 & 0 & 0 \\ \text { same age or younger } & & 0 & 0 & 0 & 0 \\ \text { Friends } & 0 & 0 & 0 & 0 & 0 \\ \text { Community members } & 0 & & & & 0\end{array}$

Comments (if any)

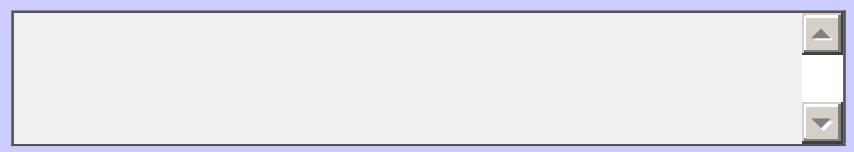


Journal of Southeast Asian American Education and Advancement, Vol. 6 [2011], Iss. 1, Art. 12

\section{NAFEA Southeast Asian American Community Survey}

39. How often do you use this language to do the following:

\begin{tabular}{|c|c|c|c|c|c|}
\hline & Frequently & Occasionally & Rarely & Never & $\mathrm{N} / \mathrm{A}$ \\
\hline $\begin{array}{l}\text { Watch movies (Video } \\
\text { tapes, DVDS) }\end{array}$ & 0 & O & O & O & 0 \\
\hline Watch online videos & 0 & 0 & 0 & 0 & 0 \\
\hline Karaoke & O & 0 & O & O & 0 \\
\hline Listen to music & 0 & O & O & 0 & 0 \\
\hline $\begin{array}{l}\text { Read books, } \\
\text { newspapers or } \\
\text { magazines }\end{array}$ & O & O & C & C & 0 \\
\hline $\begin{array}{l}\text { Read letters, notes, e- } \\
\text { mails, webpages, etc. }\end{array}$ & $\mathrm{O}$ & 0 & O & O & 0 \\
\hline $\begin{array}{l}\text { Write letters, notes, e- } \\
\text { mails, stories, poems, } \\
\text { reports, etc. }\end{array}$ & O & 0 & O & O & 0 \\
\hline
\end{tabular}

Other (please specify)

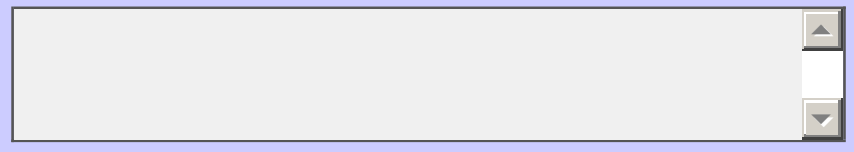




\section{NAFEA Southeast Asian American Community Survey}

40. Where do you frequently hear and use this language? [check all that apply]

Г Home

$\lceil$ Homes of relatives and friends

$\Gamma$ School

$\Gamma$ Work

- Restaurants, markets, and business establishments in the community

$\Gamma$ Christian Churches

$\lceil$ Buddhist Temples

$\lceil$ Community organizations

$\Gamma$ Parties

$\Gamma$ Weddings

ᄃ Community events

$\lceil$ Language classes and programs

○ On the Internet

$\Gamma$ On the telephone

Other (please specify)

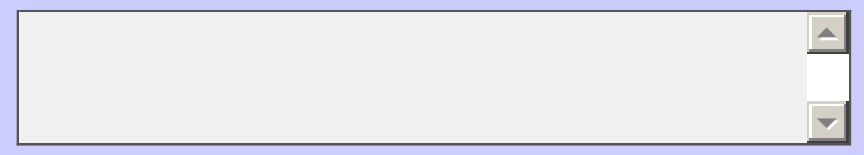

41. How often do you face difficulties communicating with parents or other family members who speak this language and who lack proficiency in English?

Frequently

Occasionally

Rarely

() Never

Comments (if any) 


\section{NAFEA Southeast Asian American Community Survey}

42. If you have visited your (or your parents') country of origin, how difficult was it to communicate with others in the native language?

Very difficult

() Somewhat difficult

Not difficult

(C) Not Applicable

Comments (if any)

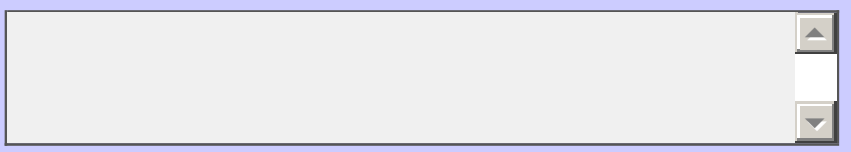

\section{Heritage Language Programs}

Heritage language programs include all programs which give students the opportunity to develop or maintain their native or heritage language. This includes in-school K-12 programs such as bilingual education and foreign (world) language classes for native speakers, college and university courses, and community-based programs after school or on the weekends.

43. Did your Elementary School(s) have any of the following types of heritage language programs in your language?

[Select "Not applicable" if you did not attend Elementary School in the U.S.]

$$
\begin{array}{lc}
\text { Yes -- and I } & \text { Yes -- but I did not } \\
\text { participated } & \text { participate }
\end{array}
$$

(

Programs

Foreign (World)

language classes

After school program

Comments (if any)

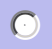

(1)

(1)
O

(1)
No

Not sure

()

(

(

\section{Not applicable}

C

O

() 
Wright and Boun: Appendix K: Survey Instrument

\section{NAFEA Southeast Asian American Community Survey}

44. Did your Middle School / Junior High School have any of the following types of heritage language programs in your language?

[Select "Not applicable" if you did not attend Middle School/Junior High School in the U.S.]

Yes -- and I Yes -- but I did not

participated participate

No Not sure Not applicable

Bilingual Education

Program

Foreign (World)

Language classes

After school program

(

()

○

(

( )

Comments (if any)

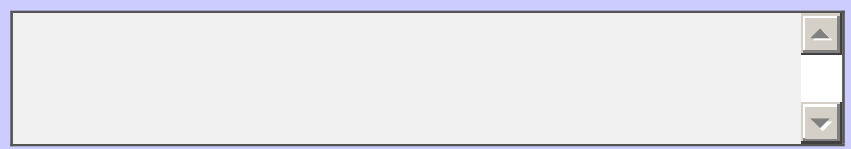

45. Did your High School have any of the following types of heritage language programs in your language?

[Select "Not applicable" if you did not attend High School in the U.S.]

$$
\begin{array}{lc}
\text { Yes -- and I } & \text { Yes -- but I did not } \\
\text { participated } & \text { participate }
\end{array}
$$

Bilingual Education

No

Not sure

Not applicable

Program

Foreign (World)

Language Classes

After school program

O

O

○

(

c

O

o

o

○

O

Comments (if any)

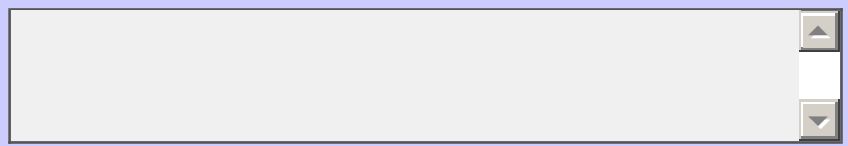




\section{NAFEA Southeast Asian American Community Survey}

46. Does your college or university have any of the following types of language programs in your language?

[Select "Not applicable" if you have not attended college]

$$
\text { Yes -- and I Yes -- but I did not }
$$

participated participate

No

○

Foreign (World)

Language Courses --

for non-natives

Foreign (World)

Language Courses --

for native speakers

Informal courses on

campus [e.g., offered

by student

organization]

Comments (if any)

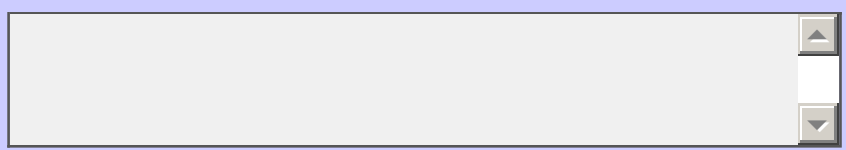

47. Were community-based heritage language programs available in the following places in areas where you lived (or currently live)?

$\begin{array}{lc}\text { Yes -- and I } & \text { Yes -- but I did not } \\ \text { participated } & \text { participate }\end{array}$

At a public school site

At a private school

site

At a Christian church

At a Buddhist temple

At the office of a

community

organization

In a private home

Other or Comments (if any) o

O

( )

o

C

C

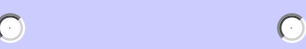

$c$

C

C

O

붕

No

Not sure

Not applicable

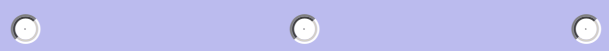

O

O

0

C

O

C

(

C

C

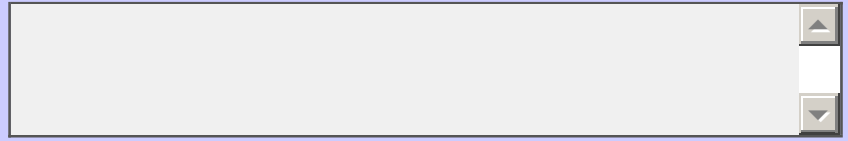




\section{NAFEA Southeast Asian American Community Survey}

48. Please indicate your level of agreement with the following statements:

\section{Strongly Agree Agree}

I am satisfied with my

level of proficiency in

my native/heritage

language.

I would like more

opportunities to

improve my

proficiency in my

native/heritage

language.

We need more

Southeast Asian

language programs

and classes in $\mathrm{K}-12$

schools, colleges and

universities.

We need more

community-based

Southeast Asian

language programs.

More Southeast Asian

students would

participate in these

language programs if

they were available.

Comments (if any)
C

o

0

0

O

0

O

0

Disagree

Strongly Disagree

Not sure

()

c)

C

0

O

(

(

C

O

O

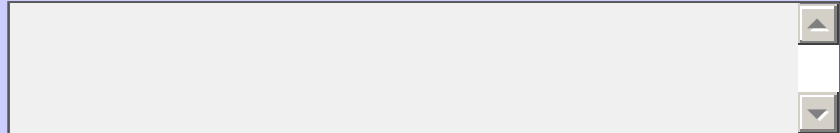

\section{Higher Education Participation}

Higher Education refers to education after high school, including colleges, universities, and technical schools.

* 49. Are you a current or former college, university, or technical school student?
O Yes
No

Comments (if any) 


\section{NAFEA Southeast Asian American Community Survey}

\section{Southeast Asian American Higher Education Access and Opportunities}

50. How much support and encouragement to attend college did you receive from the following people?

Strong support and Some support and Little to no support or encouragement encouragement encouragement

\section{Parent(s)}

High school

counselors/administrators

Teachers

Friends

Community organization

Religious organization

Others or comments (if any)

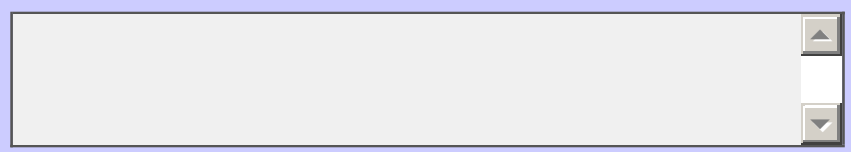

51. Who helped you with the college application process? (mark all that apply)

Г Parent(s)

Г Other family member(s)

Г High school counselor/administrator

- Teacher

$\Gamma$ Friend

Г Community organization member

$\square$ Religious organization member

$\Gamma$ No one -- I did it all on my own

Other(s) or comments (if any)

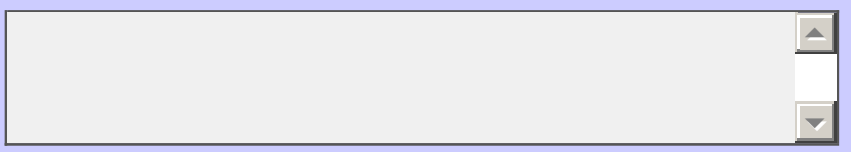




\section{NAFEA Southeast Asian American Community Survey}

52. How are you financing your college education? (Mark all that apply)

$\square$ Financial support from parent(s)

Financial support from spouse or partner

$\square$ Financial support from other family member(s)

— Scholarships

Г Student Loans

Г Work study

$\square$ Personal savings

$\Gamma$ Through working jobs while in college

Other(s) or comments (if any)

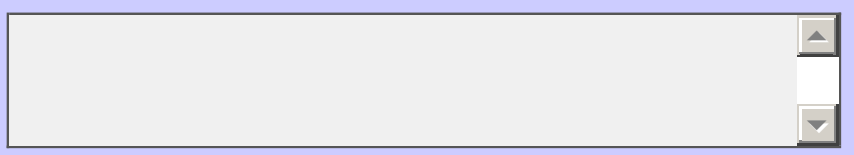

53. What obstacles, if any, did you experience in getting into college? Rate each on a scale of 1 (Not an obstacle) to 5 (Major obstacle)

\begin{tabular}{|c|c|c|c|c|c|c|}
\hline & $\begin{array}{l}1-- \text { Not an } \\
\text { Obstacle }\end{array}$ & 2 & 3 & 4 & $\begin{array}{l}5 \text {-- Major } \\
\text { Obstacle }\end{array}$ & Not applicable \\
\hline $\begin{array}{l}\text { Lack of information } \\
\text { about college }\end{array}$ & C & 0 & 0 & 0 & O & 0 \\
\hline $\begin{array}{l}\text { Parent's lack of } \\
\text { information about } \\
\text { college }\end{array}$ & 0 & 0 & 0 & 0 & 0 & 0 \\
\hline $\begin{array}{l}\text { Parental lack of } \\
\text { support }\end{array}$ & 0 & 0 & 0 & 0 & O & 0 \\
\hline Cost of tuition and fees & 0 & 0 & 0 & 0 & 0 & 0 \\
\hline $\begin{array}{l}\text { Cost of books and } \\
\text { materials }\end{array}$ & O & 0 & 0 & 0 & 0 & 0 \\
\hline Living away from home & O & 0 & 0 & 0 & C & 0 \\
\hline Transportation & O & 0 & O & O & C & 0 \\
\hline
\end{tabular}




\section{NAFEA Southeast Asian American Community Survey}

54. What challenges do you face in attending and staying enrolled in college?

\begin{tabular}{|c|c|c|c|c|c|}
\hline & $\begin{array}{l}1 \text {-- Not a } \\
\text { challenge }\end{array}$ & 2 & 3 & 4 & $\begin{array}{l}5 \text {-- Major } \\
\text { challenge }\end{array}$ \\
\hline Financial costs & O & 0 & 0 & 0 & 0 \\
\hline $\begin{array}{l}\text { Uncertainty about what } \\
\text { to major in }\end{array}$ & 0 & 0 & 0 & 0 & 0 \\
\hline $\begin{array}{l}\text { Academic difficulty of } \\
\text { courses }\end{array}$ & 0 & 0 & 0 & 0 & 0 \\
\hline $\begin{array}{l}\text { English language } \\
\text { demands of courses }\end{array}$ & 0 & 0 & 0 & 0 & 0 \\
\hline $\begin{array}{l}\text { Understanding course } \\
\text { reading assignments }\end{array}$ & O & 0 & 0 & 0 & 0 \\
\hline Writing ability & 0 & 0 & 0 & 0 & 0 \\
\hline $\begin{array}{l}\text { Lack of advising to } \\
\text { take the correct or }\end{array}$ & 0 & 0 & 0 & 0 & 0 \\
\hline
\end{tabular}

best courses

Lack of child care

Balancing family,

school, work, and

$0 \quad 0 \quad 6$

social life

Lack of support

programs (e.g., writing

assistance, tutoring

centers, counseling,

etc.)

Feelings of isolation or

loneliness on campus

Pressure to seek or

focus on full-time work

$\frac{c}{c} d$

0

0

O 0

Other or comments (if any)

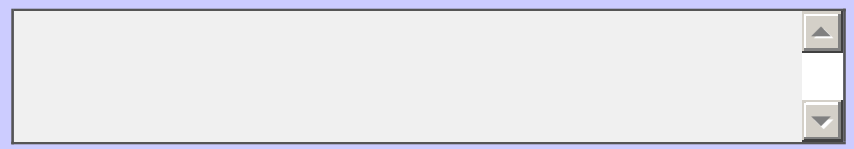

\section{Southeast Asian American Communities}




\section{NAFEA Southeast Asian American Community Survey}

55. Within the Southeast Asian American communities you are familiar with, please rate the level of severity (on a scale of 1 to 5 ) of problems associated with the following social issues:

\begin{tabular}{|c|c|c|c|c|c|c|}
\hline & $\begin{array}{l}1 \text {-- Not a } \\
\text { Problem }\end{array}$ & 2 & 3 & 4 & $\begin{array}{l}5 \text {-- Major } \\
\text { Problem }\end{array}$ & Don't know \\
\hline Gang violence & C & 0 & 0 & 0 & O & 0 \\
\hline Alcohol abuse & 0 & 0 & 0 & 0 & 0 & 0 \\
\hline Drug abuse & 0 & 0 & 0 & 0 & O & O \\
\hline Smoking & 0 & 0 & 0 & 0 & 0 & 0 \\
\hline Teen pregnancy & 0 & 0 & 0 & 0 & O & O \\
\hline Early marriage & 0 & 0 & 0 & 0 & 0 & 0 \\
\hline High school dropouts & 0 & 0 & 0 & 0 & 0 & 0 \\
\hline Domestic violence & 0 & 0 & 0 & 0 & 0 & 0 \\
\hline Child abuse & 0 & 0 & 0 & 0 & 0 & 0 \\
\hline Welfare dependency & 0 & 0 & 0 & 0 & 0 & 0 \\
\hline Unemployment & 0 & 0 & 0 & 0 & 0 & O \\
\hline Lack of job skills & 0 & 0 & 0 & 0 & 0 & 0 \\
\hline $\begin{array}{l}\text { Deportations of legal } \\
\text { residents }\end{array}$ & O & 0 & 0 & 0 & O & O \\
\hline $\begin{array}{l}\text { Illegal immigrants from } \\
\text { Southeast Asian } \\
\text { countries }\end{array}$ & 0 & 0 & 0 & 0 & 0 & 0 \\
\hline $\begin{array}{l}\text { Lack of access to } \\
\text { medical care }\end{array}$ & O & 0 & 0 & 0 & O & O \\
\hline $\begin{array}{l}\text { Lack of access to } \\
\text { mental health services }\end{array}$ & 0 & 0 & 0 & 0 & 0 & 0 \\
\hline Lack of role models & 0 & 0 & 0 & 0 & 0 & 0 \\
\hline $\begin{array}{l}\text { Lack of strong } \\
\text { community leaders }\end{array}$ & 0 & 0 & 0 & 0 & 0 & 0 \\
\hline $\begin{array}{l}\text { Lack of strong } \\
\text { community } \\
\text { organizations }\end{array}$ & O & 0 & 0 & 0 & O & O \\
\hline $\begin{array}{l}\text { Lack of representation } \\
\text { in local government }\end{array}$ & 0 & 0 & 0 & 0 & 0 & 0 \\
\hline
\end{tabular}

Others and/or Comments (if any)

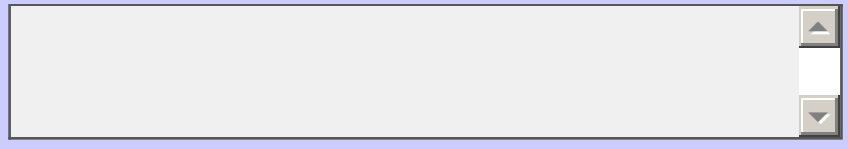


Journal of Southeast Asian American Education and Advancement, Vol. 6 [2011], Iss. 1, Art. 12

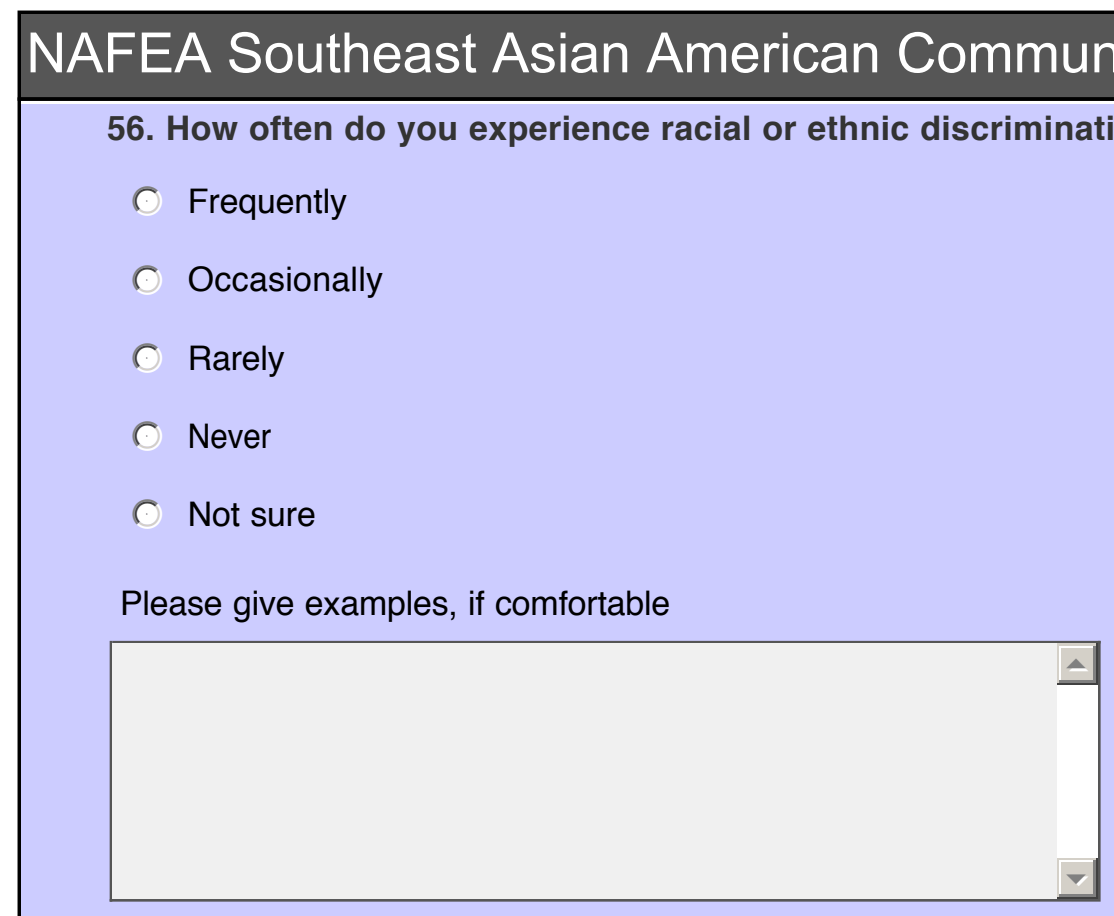


Wright and Boun: Appendix K: Survey Instrument

\section{NAFEA Southeast Asian American Community Survey}

\section{Please indicate your level of agreement with the following statements:}

\section{Strongly Agree}

Southeast Asian

Americans have made

tremendous progress

over the past 35 years

since initial refugee

resettlement.

Southeast Asian

Americans maintain a strong sense of ethnic identity and cultural pride.

Proficiency in one's native language is essential for cultural identity.

There is a need for more leadership opportunities for Southeast Asian

American youth and young adults.

Successful Southeast Asian Americans have a duty to give back to their communities.

There is a need for strong, local

Southeast Asian

American community organizations.

There is a need for strong, national

Southeast Asian

American

organizations.

Comments (if any)

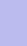

Agree

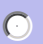

(1)

Disagree

o Strongly Disagree 


\section{NAFEA Southeast Asian American Community Survey}

Thank you for participating in this survey! At the completion of this study, results will be published in the Journal of Southeast Asian American Education and Advancement (www.jsaaea.org).

To give credit to your student organization for participation, please indicate your school in the box below (optional). This info will be kept confidential and results for individual campuses will not be reported.

If you have additional thoughts about your experiences with $\mathrm{K}-12$ education, language programs, higher education, or community issues, please share them in the boxes below.

58. Name of your university, college or school: (optional)

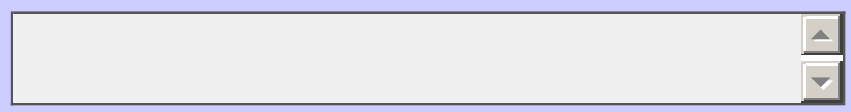

59. Additional thoughts related to K-12 Education: (optional)

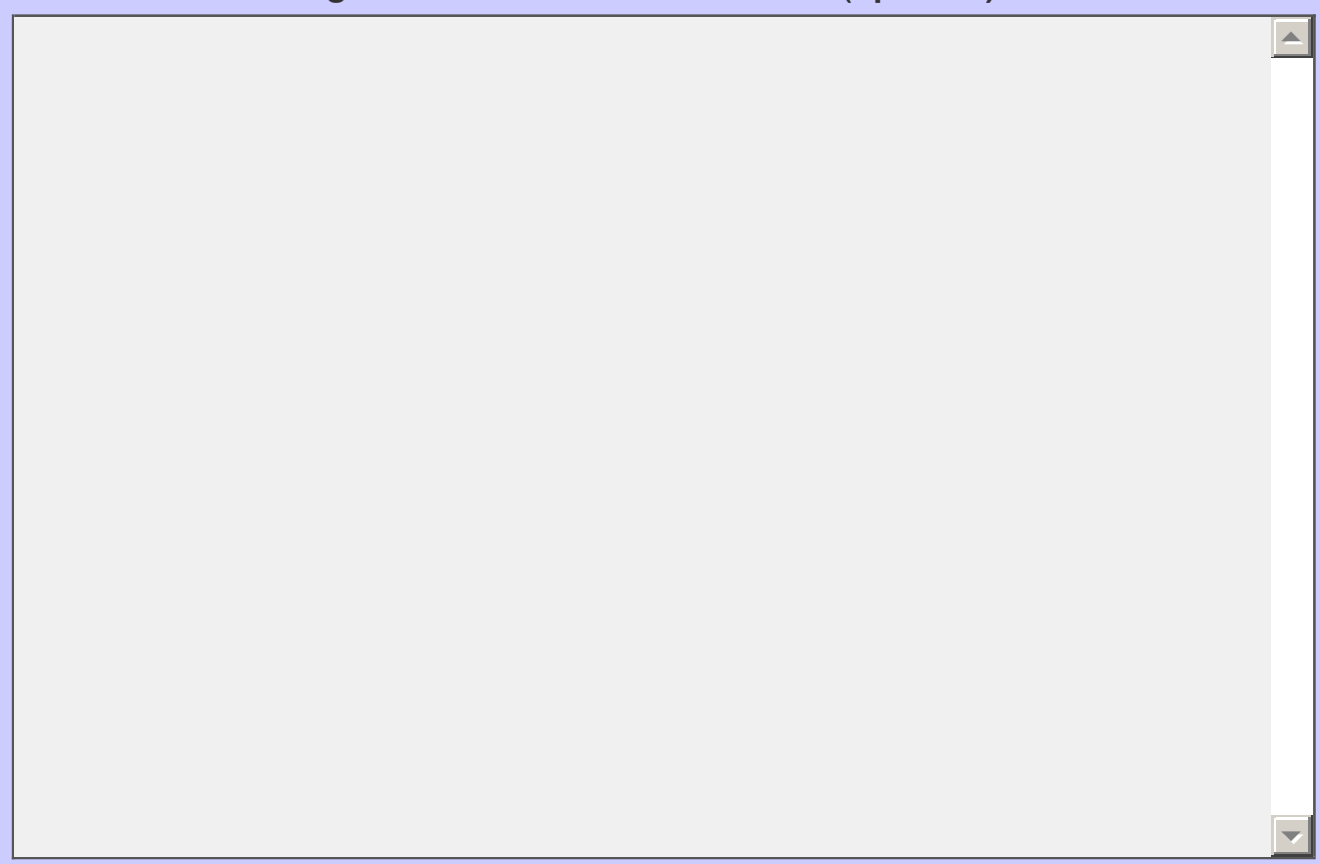


Wright and Boun: Appendix K: Survey Instrument

NAFEA Southeast Asian American Community Survey

60. Additional thoughts related to language issues and programs: (optional)

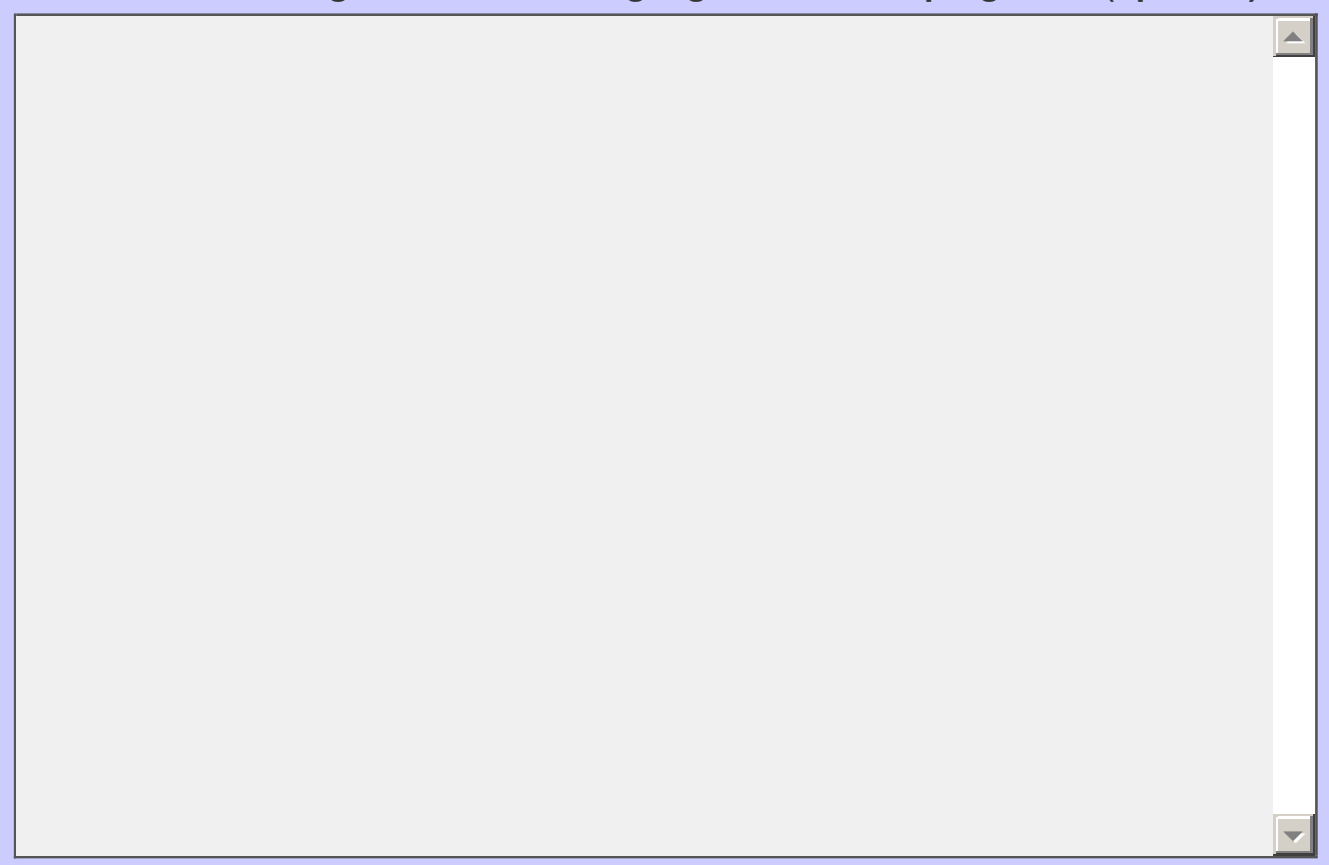

61. Additional thoughts related to higher education issues: (optional)

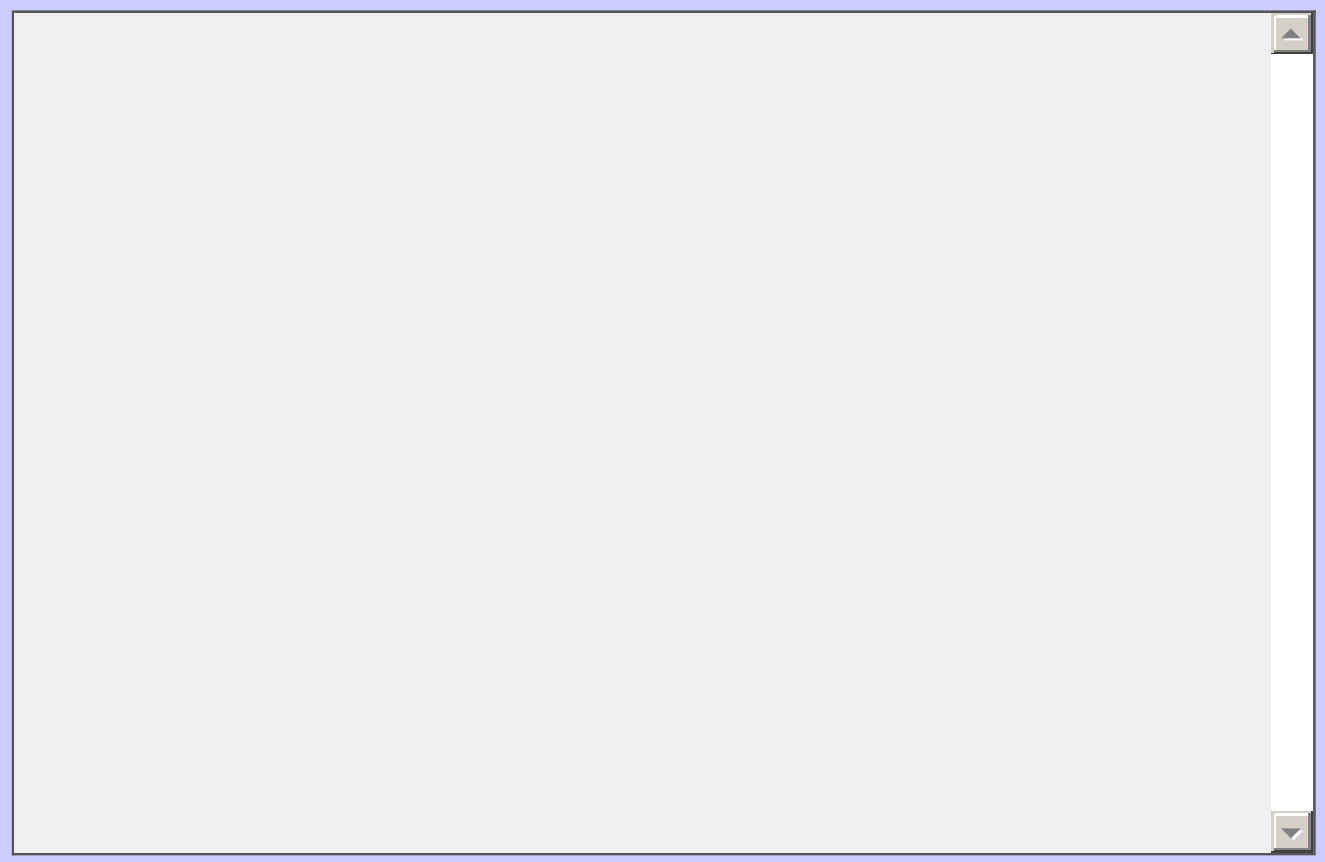


Journal of Southeast Asian American Education and Advancement, Vol. 6 [2011], Iss. 1, Art. 12

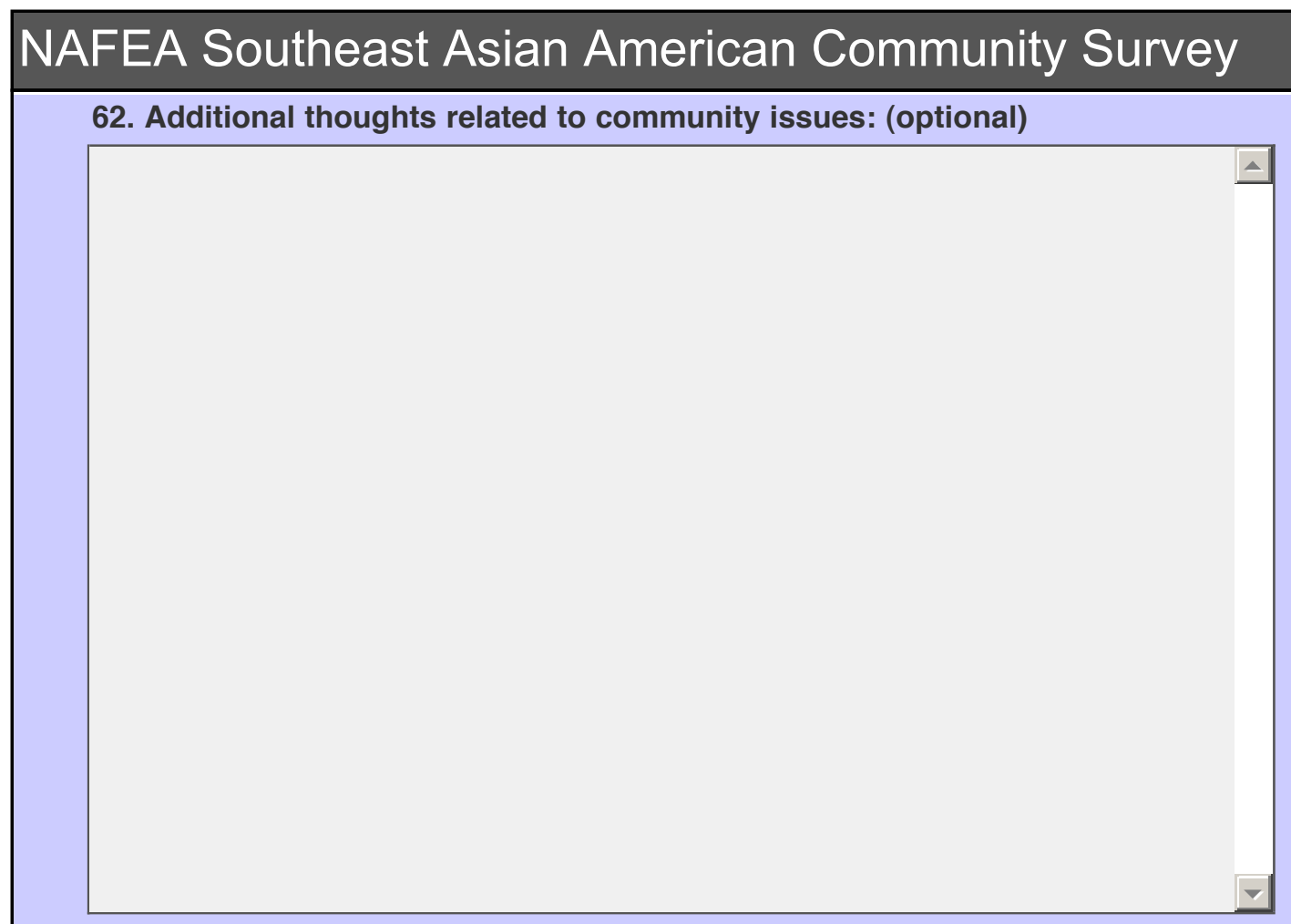

63. Please share any feedback you may have about this survey: (optional)

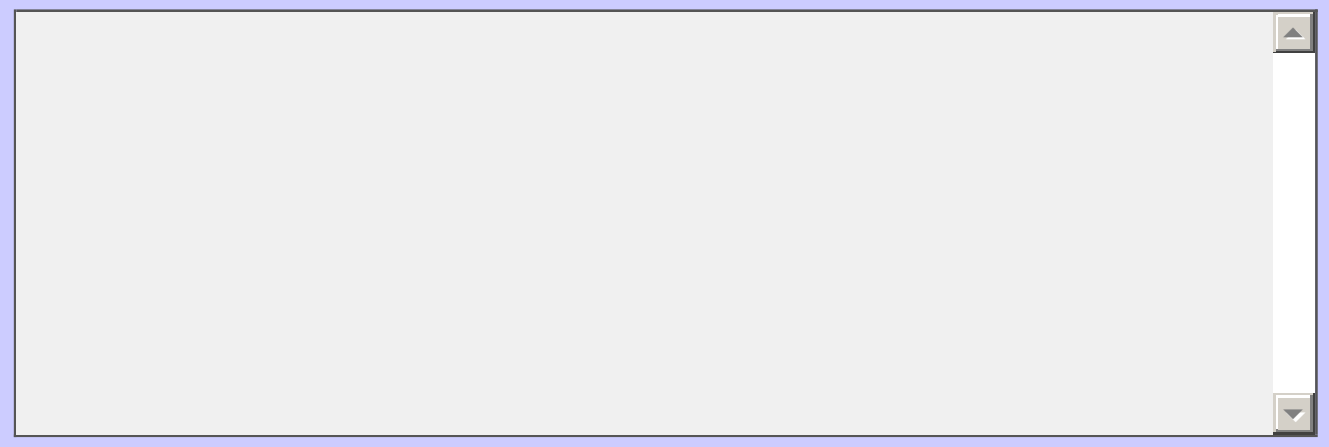

